\title{
Geo-service Industry Analysis: Scanning Challenges and Opportunities for Sustainable Asia- Pacific
}

\author{
Tamer Zaki Fouad Mohamed
}

PhD student, College of Business, Southern Taiwan University of Science and Technology, Taiwan Email: DA51G206@STUST.EDU.TW ; HARD_PILOT45@HOTMAIL.COM

\begin{abstract}
Global environmental risks resulted mainly from irresponsible industrial policies and polution, have a destructive impact on economies and societal wellbeing, especially in the Asia-Pacific. The Geoservice industry is increasingly contributing to global sustainability and welfare by providing many solutions to environmental and socio-economic issues. The industry is growing fast in the Asia-Pacific, yet there are various issues hindering industry and technology diffusion as well as many opportunities which can be harvested for better industry growth. There is much confusion and lack of studies on this new growing industry, therefore the paper attempts to simplify and clarify the structure and interdeciplinary concept of geoservices. The purpose of this study is to explore and assess the opportunities and threats influencing geoservice industry growth and diffusion in the Asia-Pacific. Methodology of such analytical descriptive study relied on secondary data and baseline information to examine and understand the industry issues and characteristics in the region. The paper also adopted various industry analysis and assessment tools such as PESTLE, Porter and Strategic Grouping analysis to support decision makers in considering the challenges and opportunities for investment and engagement in that industry. The key contribution and significance is to promote and raise awareness among general public, government and non government stakeholders on the issues hindering geospatial industry diffusion as prerequisite for sustainability in the Asia-Pacific. The paper also suggested solutions and recommendations for decisionmakers to foster industry diffusion and understand opportunities for investment.
\end{abstract}

Keywords: PESTLE, Strategic Grouping, Porter 5-forces, Geospatial, Aerospace, Asia-Pacific

\section{Industry Background}

According to recent UN report, the Asia-Pacific (APAC) is still the world's most natural disasterprone area with over $60 \%$ of the world's hungry people due to the significant disasters reaching 1690 incidents between 2004 and 2013, over $41 \%$ of worldwide incidents. During this period disaster-induced deaths reached 713,956 while economic damages were over $\$ 560$ billion. Although the report shows that the region is achieving slow economic growth, on the other hand there is a high potentiality for a faster and higher economic take off, if APAC countries would work and collaborate harder in dealing with sustainability issues (UNESCAP, 2014).Sustainability is the process and science which relies on the management and diffusion of knowledge and innovation to handle the issues and needs of current and future generations, while considering the integrity and security of nature, economy and social systems. (Lankauskienè \& Tvaronavičienè, 2012), (Choucri, 2007; Kumazawa et al., 2014).

Geospatial technologies and aerospace information services do not only have societal and environmental benefits, but also sustainable economic impact worldwide (Kerski, 2014;Oxera, 2013a;Oxera, 2013b;Ball, 2013;DUBOFF, POTIN, \& RODRIGO, 2013).

Geoservice or Geospatial industry is up to 10 times larger than the vedio games industry and up to one third the size of the global airline industry. This rappidly booming and expanding industry draws upon the upstream commercial applications of aerospace spatial technologies and the downstream business applications of Location Based Services (LBS) including but not limited to resource management, supply chain logistics, infrastructure design, telecommunications, national defense, satellite, space and manufacturing industries. Geoservices can be defined as ,interactive digital mapping and LBS that include satellite imagery, satellite positioning signals, navigation devices, and digital maps" (Oxera, 2013a). This paper focus on the upstream sector of geoservice and aerospace industry, especially remote sensing, navagational and geospatial. 


\section{Industry Analysis Methodology and Tools}

Industry analysis is the use of analytical tools to help corporations and organizations understand the forces within the industry that affect profitability. In line with porter' forces, industry can be influenced by entry and exit barriers as well as suppliers and buyers whom are affected by substitutes and other influencers. However, a more holistic approach analyzing those forces in alignment with business environment factors such as political, demographics, economic, legal, technological, infrastructure, ecological and social. (Jenster \& Hussey, 2001).

The key industry analysis factors of external business environment can be represented in PEST or STEP analysis including political factors analyzing the political progress and regulatory framework shaping the code of conduct; the economics factors and conditions affecting society and industry; social demographics, life style and values triggering shifts and trends of social transition and development; and the technological advancements and trends of new products, materials, processes, research and developments in the industry. A more comprehensive view of understanding and analyzing industry and business environment is through the iceburge model in which the structure factors including PEST and others (i.e. ecology) are the base of analysis in which trends and patterns are based on. Then comes the events at the top of iceburge as a consequence of such trends and patterns (Jansson, 2007). PEST analysis is applicable for geospatial industry, where political factors would include investment and taxation policy, prestige, international conflict or cooperation, administrative\& governance and civil-military relations. The economic factors would include unemployment, new business models, public private partnership\& business cycle. Sociocultural factors would include standard of living, lifestyle changes and level of education and training. Technological factors would include new discoveries, ICT developments, as well as technology transfer and obsolescence rate. The extended version of PEST adds two more dimensions, the legal and environmental for deeper analysis. Recently it has been further extended to include ethics and demographics i.e. STEEPLED. Those factors represent the changes, trends and future expected scenarios in each context. After identifying those factors in the organizational related context or industry, the next step is to identify implications for each of those factor groups and priorities them based on assessment rating such as: High or significant impact \low or insignificant impact, Short term impact long term impact, positivel negative impact as well as the low $h$ high likelihood of happening and the dynamic nature of impact if its unchanged, increasing or decreasing. (Trodd, 2007). External business environment involve general, industry and competitor environments. The general environment involves the dimensions in the broader society influencing the industry and companies within, such as demographic, economic, physicallnatural, socio-cultural, global, technological, and politicallegal factors. The industry and competitor environment is a deeper level analysis involving factors directly influencing companies and competitiveness in the market such as Porter 5 forces, benchmarking and competitor intelligence. External environment analysis tries to highlight the opportunities or the conditions in the general environment which can be exploited to help companies become more competitive as well as threats in the general environment hindering the company' efforts in achieving strategic competitiveness.

Table 1. Components of external environment analysis

(Hitt, Ireland, \& Hoskisson, 2017).

\begin{tabular}{|l|l|}
\hline Scanning & Identifying early signals of environmental changes and trends. \\
\hline Monitoring & Detecting meaning through ongoing observations of environmental changes and trends \\
\hline Forecasting & Developing projections of anticipated outcomes based on monitored changes and trends \\
\hline Assessing & $\begin{array}{l}\text { Determining the timing and importance of environmental changes and trends for firms' } \\
\text { strategies and their management }\end{array}$ \\
\hline
\end{tabular}

The key components of external environment are the economic, technical, political-legal, ecological and socio-cultural factors as represented in STEEP or PESTLE analysis. On the other hand, task environment" stakeholders include governments, local communities, suppliers, competitors, customers, creditors, employees, labor unions, special interest groups, and trade associations. Industry analysis considers the dynamic and task environment ${ }^{\circ}$ factors as they negatively or positively affect the business (i.e. resource availability and cost) as well as the 
industry (i.e. growth and decline). Michael Porter popularized industry analysis especially by introducing the 5 forces as follows: leveraging the bargaining power of suppliers, superior or lower cost substitute products, competition among existing companies, openess to new competitiors or entrants, and the bargaining power of buyers and their influence. Another key industry analysis is strategic grouping in which two broad dimensions or variables which are independent but related such as price, product-line breadth, quality and vertical integration. Consequently, companies can be grouped in circles within the $\mathrm{X}$ and $\mathrm{Y}$ variables according to their close or similar characteristics (Wheelen \& Hunger, 2015). Mapping strategic groups was initiated by porter to help organizations categorize different groups of companies and competitors with similar strategic characteristics within two axis of variables such as specialization and vertical integration (Jenster $\&$ Hussey, 2001). Other variables of strategic group analysis include technological leadership and distribution channels, while other benefits invlude helping members of each group to understand market positioning, easily identify suitable business models and strategies as well as structuring, analysing and diagnosing corporate and industry competitiveness. Competition within one group circle of similar companies are more intensive than with those outside group circle. (Hitt et al., 2017).

This paper focus on the scanning phase of analysis. However, future research can also focus on competitor and stakeholder analysis, BCG, value chain and value network analysis as well as monitoring, forecasting and assessing geo-service industry in the APAC.

\section{Scanning Geoservice Challenges and Opportunities in the Asia-Pacific}

The following strategic group map shows key APAC countries competing in the aerospace and geospatial industry. The grouping is based on specialization and vertical integration to understand the general position of key players and their competitiveness in the global market. There is a great opportunity for coopetition not within each group but among different groups through multinational alliances and consortia, in which the more advanced groups in vertical integration and specialization can offer upstream products and services as tier1 and tier2, while less advanced groups can support with downstream tier 3 and tier 4 products and services. However, establishing, managing and sustaining such alliances constitute a great challenge.

\section{Vertical Integration (Y Axis)}

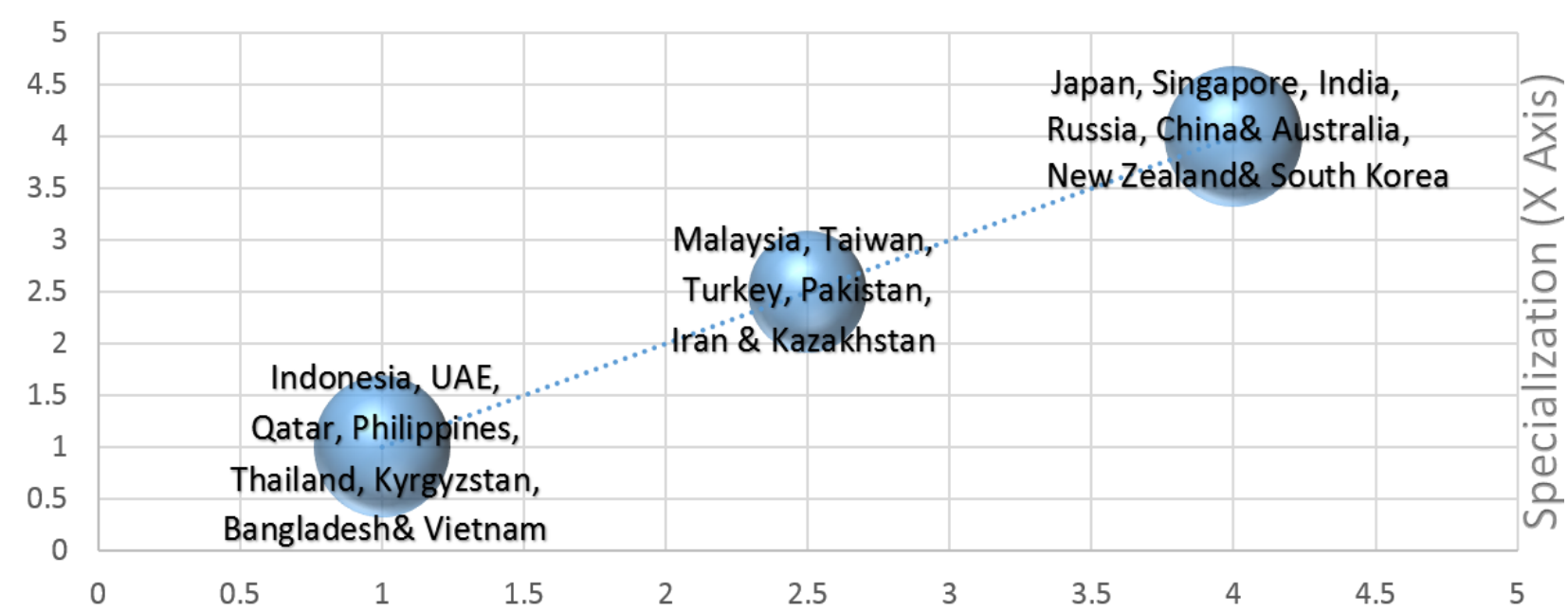

Figure 1. Strategic Group Map for Asia and Pacific Geo-service Industry

The following table summarizes key factors of porter 5 forces industry analysis

Table 2. Porter 5 forces analysis for Asia-Pacific geoservice industry 


\begin{tabular}{|l|l|}
\hline $\begin{array}{l}\text { Suppliers power } \\
\text { (Medium-High) }\end{array}$ & $\begin{array}{l}\text { The high switching cost and lack of competitive suppliers makes the leading } \\
\text { companies have high bargaining powers especially for high-end products and } \\
\text { services, while suppliers from emerging markets still can negotiate with buyers for } \\
\text { low end products and services. For instance, Chinese Beidou navigational satellite } \\
\text { system is becoming competitive against GPS in Asia }\end{array}$ \\
\hline $\begin{array}{l}\text { Buyers power } \\
\text { (Low) }\end{array}$ & $\begin{array}{l}\text { Demand from buyers is still not promising due to the lack of marketing and } \\
\text { diffusion efforts in which societies are not prepared or aware regarding the } \\
\text { potential of geospatial applications and extended benefits, in addition to the high } \\
\text { price of geo-services for end-users in many developing countries. However, the } \\
\text { bargaining power is low because they don't have many alternatives of suppliers } \\
\text { when they need geo-services. }\end{array}$ \\
\hline $\begin{array}{l}\text { Industry rivalry } \\
\text { (Low-Medium) }\end{array}$ & $\begin{array}{l}\text { High competition among leading companies from China, Japan, Singapore, India, } \\
\text { Australia and Russia while other emerging competition arises from New Zealand, } \\
\text { South Korea, Malaysia, Turkey, Iran, Taiwan, Pakistan, Iran, and Kazakhstan. } \\
\text { However, low competition is from beginners such as Indonesia, UAE, Qatar, } \\
\text { Philippines, Thailand, Kyrgyzstan, Bangladesh and Vietnam. }\end{array}$ \\
\hline $\begin{array}{l}\text { New entrants } \\
\text { (low) }\end{array}$ & $\begin{array}{l}\text { The industry still has high entry barriers due to the high risk and investment cost } \\
\text { as well as technology sophistication and competitiveness of leading companies. } \\
\text { However, establishing and sustaining industry alliance could expand the market } \\
\text { and open opportunities for smaller companies }\end{array}$ \\
\hline $\begin{array}{l}\text { Substitutes } \\
\text { (Medium) }\end{array}$ & $\begin{array}{l}\text { Drones are becoming more reliable, effective and efficient as enabling technology } \\
\text { for remote sensing business and applications while future technologies such as } \\
\text { high-altitude balloons (i.e. stratobus) can be more reliable, effective and efficient } \\
\text { substitute to many satellite services. }\end{array}$ \\
\hline
\end{tabular}

Industry challenges and opportunities are mainly focusing on external environment factors (i.e. PESTLE) rather than corporate factors (i.e. SWOT), therefore the following baseline information is collected from literature and reports to outline the following key factors:

\section{Political}

Key policy barriers and threats for aerospace and geospatial industry diffusion can be outlined as the lack of clear vision and understanding of establishing aerospace innovation system and business model to acquire and develop the technology and industry resulting issues in safety, quality and labor. Moreover, lack of legal, organizational, and financial backing as well as trust and collaboration issues due to policy barriers, security control, monopoly and corruption. Another key factor is western hegemony and control over the global aerospace market either by controlling the technologies i.e. limiting GPS services or through unfair export control policies i.e. ITAR (Fouad, Cheng, \& Su, 2015). On the other hand, the unstable political and security situation in APAC due to environmental and man-made disasters, potential terrorism, boarder disputes (i.e. South China Sea), over fishing and sea resources as well as the north Korean intimidation creates opportunities out of threats for business and commercial sector, especially by initiating an arms race and fierce competition on developing aerospace capabilities for situational awareness and defense (Stokes \& Easton, 2012).

\section{Economic}

This paper affected by the scarcity and high cost for accessing aerospace industry data and reports. However, it is possible to understand the general trend of aerospace industry growth in the region based on available data. For instance,one report indicates that the top Asian countries among the top 15 global lists for exporting aerospace products in 2015 are Singapore with $\$ 6.4$ billion (1.8\%), Japan with $\$ 5.17$ billion (1.47\%), India with $\$ 3.78$ billion (1.07\%), and China with $\$ 3.5$ billion (1\%). Although such figures are too general since the aerospace industry include aeronautics and astronautics, but in general both technologies complement and support each other indicating strong aerospace capabilities and business potential. (WORKMAN, 2016). According to 2013 report, The annual revenues of global aerospace manufacturing industry exceeded $\$ 700$ 
billion in which the largest markets for aerospace product sales were North America and Europe followed by the emerging economies in the APAC region which expected to provide the greatest growth opportunities in the future(First-Research, 2013). Moreover,APAC region is the fastest growing market for UAVs mainly for security applications. However, some countries adopting UAVs for commercial purposes such as Taiwan and Pakistan. The whole region is interested in UAVs while Key investing countries are Australia, China, Japan, North Korea, South Korea, Singapore, Indonesia, Malaysia, Philippines and Thailand. In 2011 APAC was the second largest region after the United States, spending US \$590 million on UAVs and estimated to reach US \$1.4 billion per year by 2017 (Sanindu, 2013). Geo-Service industry has a global value reaching \$270 billion in which $\$ 90$ billion of that paid in wages to workers, and making up roughly $0.2 \%$ of global gross domestic product (GDP). The diffusion of Geo services is growing globally with $30 \%$ increases per year, while $50 \%$ of Internet users accessing maps online, and $35 \%$ using maps on smartphones. The industry has a high demand potential for skills with job growth of $22 \%$ for cartographers, $16 \%$ for survey/ mapping technicians, and 35\% for geographers. Moreover, the APAC in the nascent stage of growth in terms of growing jobs and growing value of services, bypassing other more developed parts of the world. Such diffusion is expected to increase as digital maps get better and more accessible. To sustain this diffusion growth, a broader awareness and promotion is needed as well as more investment from governments and companies to foster open data policies, more geographic education, and product innovation especially in earth observation (Ball, 2013). Furthermore, the western model of public private partnership for aerospace industry growth is followed successfully by Asian growing aerospace powers in which civilian space program funded by the government through tax collection and implemented in collaboration with private and research entities (Angelis, 2013). Developing a stable business model for space industry may take long time to achieve profitable success, however it may have short term achievements if outer space is to serve the immediate ends of sustainability. In order to achieve industry growth, policies are recently pushing towards furthering competition towards increased timely access and availability as a priority then raising the importance of copyright protection and licensing management. issues such as pricing, revenues and balancing supply with demand according to different users and needs should be handled within an integrated value-added products and services or within alliance collaborative structures and not only relying on economic copyrights. Both up and down streams are looking to develop space markets and products where a successful model requires both creativity and collaboration between the public and the private sectors (Smith, 2011).

\section{Socio-cultural}

Another factor required for LBS diffusion in the APAC is the social factor triggered by lifestyle and consumer behavioral patterns that should be considered by LBS providers in order to provide tailored applications and services to their needs and environment. For instance, Japan and South Korea supported innovative LBS applications for community creation, child-locator services and crime-prevention (Frost \& Sullivan, 2008). Asia is one of the most promising regions in the diffusion of remote sensing and earth observation applications. On the other hand, western countries have more government support and funding but less interest from students compared to APAC(Noort, 2011).LBS have promising future especially in the APAC. One Study examined cell phone users among 48,000 people in 58 countries indicatinga growing global societal awareness and interest about the benefits and applications offered by LBS especially where almost one third of world populations are using smart phones while in developed APAC countries such as Japan, Korea, Australia, Singapore, Taiwan, Malaysia and New Zealand, the percentage is also high making the region' customers eager to adopt LBS(Coordinates, 2012).

\section{Technological}

Some of the related LBS technological barriers that service operators find difficulty to get the best deal from LBS provider in terms of cost and complex choices of LBS offerings which also create interoperability issues. Other issues include privacy, service quality, fair access and use of LBS data, and technologylservice standardization. However, some markets in Europe and Asia are successfully developing LBS such as Sweden and Japan. The trend is showing a great potential for LBS diffusion with the development of information and communication technologies if the technical and policy issues have been dealt with (Steinfield, 2004).LBS market growth and 
diffusion in the APACis improving in which related technologies and infrastructure i.e. 4G and GPS is getting widely available at lower cost. Other drivers leading diffusion in the region the advancement of Cell-ID, E-OTD, OTDOA, A-GPS, E-GPS, and hybrid Technology as well as the strong competition of enterprises trying to attract customers by providing them suitable services such as Cisco, Microsoft, ESRI, Blackberry, Facebook, and Masternaut. Moreover, the customer base of LBS is also increasing as they are getting more interested in benefiting from LBS opportunities and extended applications such as navigation, mobile advertisements, tourism, and consumer tracking. (PRWeb, 2014).GPS and related LBS for the APAC region. Singapore with $150 \%$ mobile penetration rate is becoming a leader market in LBS and its Apps became one of the most fundamental for smartphone and tablet users. Although GPS is enabled by satellite requiring a line of sight under the sky, both companies are now developing a wireless based GPS like system to expand LBS capabilities as an effort for technology diffusion with the possibility to expand its commercial applications indoors such as tracking for foot traffic, thereby deducing customer behavior from movement. This could be useful in malls, retail establishments and airports, among others. Adding indoor LBS marketing and advertising can significantly increase LBS business opportunities with new innovative Applications such as "showrooming". Singapore based LBS companies are working hard to diffuse such innovative solutions and Apps across APAC as part of its recent raising $\$ 590,000$ to expand its presence in the region(Racoma, 2013).

A growing geoservice technology trend is the use of drones or UAVs for commercial applications and LBS. This emerging trend has a growing potential business opportunity. The technology is quiet cheap and had promising results in Europe and Asia (gulf-times.com, 2013).

Small satellites technology has already been adopted by academic and business communities in Asian countries such as some Indian universities which successfully developed and even lunched satellites by local Indian students in cooperation with Russian students. Small satellites are the leading technology in the near future after smartphones and tablets in which it composes of similar functions and features such as imaging optics, radio communication, battery power systems as well as processing ICs and other sensors. However, High processing power microcontrollers are still not widely available and affordable for commercial diffusion. (John, Schingler, \& Edgar, 2013). Such small satellites can be even more reliable and successful than traditional satellites if they are integrated and utilized in a fleet of small satellite constellation. On the other hand, privacy issues raise security concerns for the misuse of such capability. Yet, some Asian countries try to legalize, control and monitor aerospace business activities such as the Indian space authorities (John et al., 2013).

R\&D collaboration between Sprooki and YFind in Singapore is one example to enable indoor.

\section{Legal}

India and Japan are developing regulatory system to support their ambitious aerospace policies for commercial growth and investment. Yet, it remains a global challenge to effectively integrate aerospace and related geospatial activities into civil regulations due to safety, security and privacy issues among others, especially regarding the commercial use of drones. Other legal issues include the use of open GIS standards and intellectual property as well as the impact of viewing certain areas on digital maps in which boarders disputed by different countries (Deogawanka, 2015). Other legal issues related to spatial information include the protection of data privacy and confidentiality for individuals or organizations. Considering and complying with national laws and corporate contracting for the exchange of spatial data and information products and managing its liability terms and conditions (Smith, 2011).

\section{Ecological}

The study referred to huge environmental and socioeconomic benefits relying on remote sensing and earth observation applications and expected to have greater potential for growth in the future especially if technology developers provide more practical capacity building support to less developed markets. Such worldwide diffusion will have significant impact in solving global sustainability issues (Noort, 2011). On the other hand, the role of aerospace industry players in observing and abiding by social, economic and environmental dimensions of sustainability with reference has great benefits even to the company itself. BAe systems company in the UK followed corporate sustainability practices very effectivelyresulting a better corporate image and reputation 
among the company stakeholders and consequently driving more success and revenues (Gopalakrishnan, Yusuf, Musa, Abubakar, \& Ambursa, 2012).

Table 3. PESTLE Analysis for Geo-service industry in Asia-Pacific industrialized countries

\begin{tabular}{|c|c|c|c|c|c|}
\hline \multirow[t]{7}{*}{$\begin{array}{l}\text { Political } \\
\text { factors }\end{array}$} & APAC Geo-Analysis Factors & Importance & Likelihood & Continuity & $\begin{array}{l}\text { Overall } \\
\text { impact }\end{array}$ \\
\hline & Civil-Military Relations & Medium & High & Low-Med & High \\
\hline & Investment and Taxation Policies & High & Med-High & Low-Med & Medium \\
\hline & $\begin{array}{l}\text { International conflictl political } \\
\text { unstability }\end{array}$ & High & High & Low-Med & High \\
\hline & International cooperation & High & Med-High & Low-Med & Medium \\
\hline & Administrativel governance & High & Med-High & Low-Med & Medium \\
\hline & Prestige\& leadership power & High & High & Low-Med & High \\
\hline \multirow{5}{*}{$\begin{array}{l}\text { Economic } \\
\text { factors }\end{array}$} & Unemployment & High & Med-High & Low & Medium \\
\hline & Business Model Innovation & High & Medium & Low & Medium \\
\hline & Public-Private-Partnership & Medium & Med-High & Med-High & Medium \\
\hline & Business cycle: growth $\backslash$ decline & High & Med-High & Low & Medium \\
\hline & ROI\& profitability & High & Med-High & Low & Medium \\
\hline \multirow{5}{*}{$\begin{array}{l}\text { Socio- } \\
\text { cultural } \\
\text { factors }\end{array}$} & standard of living & High & High & Low & Medium \\
\hline & Technology lifestyle changes & High & High & Low-Med & High \\
\hline & Education and user capacity & High & Med-High & Low & Medium \\
\hline & Privacy\& socio-cultural values & Medium & Med-High & Low & Medium \\
\hline & Credible diffusion leaders & Medium & Med-High & Low & Medium \\
\hline \multirow{5}{*}{$\begin{array}{l}\text { Technical } \\
\text { factors }\end{array}$} & New discoveries $\backslash$ innovativeness & High & Medium & Low & Medium \\
\hline & ICT developments & High & High & Low-Med & Medium \\
\hline & Infrastructure & High & High & Low-Med & Medium \\
\hline & $\begin{array}{l}\text { Technology transfer and } \\
\text { capability building }\end{array}$ & High & Medium & Low-Med & Medium \\
\hline & Technological obsolescence & Medium & Medium & Low-Med & Medium \\
\hline \multirow{2}{*}{$\begin{array}{l}\text { Legal } \\
\text { factors }\end{array}$} & National governing regulations & High & Medium & Med-High & High \\
\hline & Intellectual property issues & High & Medium & Med-High & High \\
\hline \multirow{2}{*}{$\begin{array}{l}\text { Ecological } \\
\text { factors }\end{array}$} & Contribution for sustainability & Med-High & Medium & High & High \\
\hline & production\& & Medium & Medium & Med-High & Medium \\
\hline
\end{tabular}

\section{Conclusion and recommendations}

In general, satellites, UAVs and aerospace systems are very useful and important for countless geoservice applications and has great commercial opportunities, especially for APAC region which has promising growth indicators for more competitive diffusion in the future. On the other hand, APAC societies still need more marketing and awareness by governments, geoservice companies, and NGOs. On the other hand, Policy Legal, technical, privacy and economic issues should be carefully adressed to insure a wide diffusion and faster growth. However, one key barrier is the lack of strong connection and coopetition between upstream and down stream industry members, as well as the political hostilities and firce competition among major aerospace powers in the region. Therefore industry consortia of companies and industry members is more suitable than government-based aerospace alliances. Such regional industry consortia, alliance or association can rely on internet platform or spin offs to handle geoservice various issues more effectively.

\section{References}


Angelis, A. D. (2013, June 21). Global Aerospace Market. Companiesandmarkets.com. Retrieved from https://uk.finance.yahoo.com/news/global-aerospace-market-000000035.html

Ball, M. (2013, February 1). Google Invests in Market Research on the Global Geo Services Industry. Asmmag.com. Retrieved from https://www.asmmag.com/2012-12-30-14-4018/feature/4754-google-invests-in-market-research-on-the-global-geo-services-industry.html

Choucri, N. (2007). Mapping sustainability knowledge e-networking and the value chain. Dordrecht: Springer. Retrieved from http://public.eblib.com/choice/publicfullrecord.aspx?p=338426

Coordinates. (2012, May). Consumers in Asia eager to adopt location-based services. Retrieved from http://mycoordinates.org/lbs-34/

Deogawanka, S. (2015, September 9). Spatial Law and Geospatial Technologies. Retrieved from https://www.gislounge.com/spatial-law-and-geospatial-technologies/

DUBOFF, R., POTIN, D., \& RODRIGO, D. (2013). Location Based Marketing: GLOBAL MEDIA TRENDS. HAVAS MEDIA. Retrieved http://www.havasmedia.com/documents_library/insights/location-based-marketing.pdf

First-Research. (2013). Aerospace Products \& Parts Manufacturing Industry Profile. Retrieved from http://www.firstresearch.com/Industry-Research/Aerospace-Products-and-PartsManufacturing.html

Fouad, T. Z., Cheng, F. F., \& Su, H. N. (2015). Innovation Diffusion for Location Based Services in the Asia-Pacific: Anti Vs. Pro Innovation Bias. Presented at the XXVI ISPIM Conference, Budapest, Hungary. Retrieved from http://connection.ebscohost.com/c/articles/110480558/innovation-diffusion-location-basedservices-asia-pacific-anti-vs-pro-innovation-bias

Frost \& Sullivan. (2008). Growing Demand for Location-based Services (LBS) in Advanced Mobile Markets. Frost \& Sullivan. Retrieved from http://www.directionsmag.com/pressreleases/growing-demand-for-location-based-services-lbs-inadvanced-mobile-markets/116680

Gopalakrishnan, K., Yusuf, Y. Y., Musa, A., Abubakar, T., \& Ambursa, H. M. (2012). Sustainable supply chain management: A case study of British Aerospace (BAe) Systems. International Journal of Production Economics, 140(1), 193-203. https://doi.org/10.1016/j.ijpe.2012.01.003

gulf-times.com. (2013). The coming of the drones. Doha, Qatar. Retrieved from http://www.gulftimes.com/technology/233/details/349194/the-coming-of-the-drones

Hitt, M. A., Ireland, R. D., \& Hoskisson, R. E. (2017). Strategic management: competitiveness \& globalization; concepts (12e ed.). Boston: Cengage Learning.

Jansson, H. (2007). International business strategy in emerging country markets: the institutional network approach. Cheltenham: Edward Elgar.

Jenster, P. V., \& Hussey, D. E. (2001). Company analysis: determining strategic capability. Chichester; New York: Wiley.

John, D., Schingler, R., \& Edgar, T. (2013, November 5). Small Satellites: All Set To Spur Innovation. $\quad$ Electronicsforu.com. Retrieved from http://electronicsforu.com/electronicsforu/circuitarchives/view_article.asp?sno=1563\&title $\% 20=\%$ 20Small+Satellites\%3A+All+Set+To+Spur+Innovation\&b_type=new\&id=12439

Kerski, J. (2014, March). The Size of the Geospatial Industry. Retrieved from http://blogs.esri.com/esri/gisedcom/2014/03/13/the-size-of-the-geospatial-industry/

Kumazawa, T., Kozaki, K., Matsui, T., Saito, O., Ohta, M., Hara, K., ... Mizoguchi, R. (2014). Initial design process of the sustainability science ontology for knowledge-sharing to support codeliberation. Sustainability Science, 9(2), 173-192. https://doi.org/10.1007/s11625-013-0202-z

Lankauskienè, T., \& Tvaronavičienè, M. (2012). SECURITY AND SUSTAINABLE DEVELOPMENT: APPROACHES AND DIMENSIONS IN THE GLOBALIZATION CONTEXT. Journal of Security and Sustainability Issues, 1(4), 287-297. https://doi.org/10.9770/jssi.2012.1.4(5)

Noort, M. (2011). MARKETING EARTH OBSERVATION PRODUCTS AND SERVICES. ITC. Retrieved from http://www.eopower.eu/docs/marketing1.pdf 
Oxera. (2013a). what is the economic impact of Geo-Services (geoservice industry revenue executive summery prepared for Google). Retrieved from http://www.oxera.com/Oxera/media/Oxera/downloads/reports/What-is-the-economic-impact-ofGeo-services---summary_2.pdf

Oxera. (2013b, January). "Oxera quantifies the benefits of Geo services to global consumers and businesses on behalf of Google." Retrieved from http://www.oxera.com/LatestThinking/News/January-2013/Oxera-quantifies-the-benefits-of-Geo-services-to-g.aspx

PRWeb. (2014). The Asia-Pacific Location Based Services (LBS) market is estimated to grow from $\$ 1,572.4$ million in 2014 to $\$ 11,257.3$ million by 2019. PRWeb. Retrieved from http://www.prweb.com/releases/location-based/market/prweb12240127.htm

Racoma, J. A. (2013, January). Location-based marketing startup Sprooki gets a big push from YFind indoor GPS tech. e27. Retrieved from http://e27.co/location-based-marketing-startupsprooki-gets-a-big-push-from-yfind-indoor-gps-tech/

Sanindu. (2013, May 12). Asian region UAV capability on the rise. Retrieved from http://defencetalks.wordpress.com/2013/05/12/asian-region-uav-capability-on-the-rise/

Smith, L. J. (2011). Business innovation symposium "At what price? IP-related thoughts on new business models for space information." Acta Astronautica, 69(7-8), 714-721. https://doi.org/10.1016/j.actaastro.2011.04.013

Steinfield, C. (2004). The Development of Location Based Services in Mobile Commerce. In B. Preissl, H. Bouwman, \& C. Steinfield (Eds.), E-Life after the Dot Com Bust. Heidelberg: PhysicaVerlag HD: Imprint: Physica. Retrieved from http://dx.doi.org/10.1007/978-3-662-11659-3

Stokes, M., \& Easton, I. (2012). China and the Emerging Strategic Competition in Aero- space Power. In H. D. Sokolski (Ed.), The Next Arms Race (pp. 141-78). Carlisle, PA: Strategic Studies Institute Press. Retrieved from http://www.npolicy.org/books/Next_Arms_Race/Full_Book.pdf

Trodd, N. (2007). PESTLE analysis. Retrieved from http://www.gisknowledge.net/topic/eo_by_remote_sensing/trodd_pestle_analysis_07.pdf

UNESCAP. (2014). Statistical Yearbook for Asia and the Pacific 2014 (No. ST/ESCAP/2704). UN. Retrieved from http://www.unescap.org/sites/default/files/ESCAP-SYB2014.pdf

Wheelen, T. L., \& Hunger, J. D. (2015). Concepts in strategic management and business policy: globalization, innovation, and sustainability (Fourteenth Edition). Boston: Pearson.

WORKMAN, D. (2016, October 13). Aerospace Exports by Country. Retrieved from http://www.worldstopexports.com/aerospace-exports-by-country/ 